nature of the trouble was pointed out. 'The patient says that the only trouble he himself noticed was that he couldn't, throw a ball as well as formerly.

At the time of his first, visit to the City Iospital clinic the conditions were about, as at present, and as the aceompanying photgoraphs show fairly well. 'There wis a marked shoulder-drop on the right, marked supra- and infri-celovicular depressions, thinning of the cervieal border of the traperius and considerable wasting of the pectorials. P'osteriorly there was some atrophy of the suprat and infra-spinatus, with eversion and forward rotation of the right seapula. 'The right, arm eould be raised fairly woll to a right, angle with the trumk, but beyond thit only with difficulty. All other motions of the arm and hand were also weak. Motions of the head and neck were possible but distinetly limited on the right. 'The right, seapula could not, be approximated to the spine. 'The affected muscles showed varying degrees of quantitative loss to faradism.

Whe situation to-day, Fel. 23, 1907, shows but little chamge for the better, although the patient has had the benefit, of four months' treatment, by matssage and electricity.

'l'he photograph used in illustration of the conditions in this last ease may be regarded as illustrating all such eases, the only variation being one of clegree of severity.

In the matter of prognosis it need only be said that the nature of the original lesions implies permanent damare. In (ase I, the most recent of the three, a certain amount of recovery will probably take place. Case 11 may be characterized as one of "healing with defect," while a lapse of five years in (ase III practically places the damage upon a permanent basis.

The surgical lesson taught by these cases is too obvious to recpuire comment:

\section{Medical Brogregs.}

\section{R.EGLN'T PROGIRLSSS IN IARYNGOLOGY.}

$$
\begin{aligned}
& \text { "Y A. COOIUกF, JR., M.D., } \\
& \text { AND } \\
& \text { I. A. BARNES, M.D. } \\
& \text { NASAI, POLYPI. }
\end{aligned}
$$

'Tun etiology of nasal polypi has long been the wi subject of much discussion. That they are the result of underlying inftammation or disease is. now undoubtel. An interesting contribution to this subject appears in a recent monograph by Yonge. ${ }^{1}$

The author's position is strengthened by having produced polypi artificially in cats which he subjected to the conditions under which he believes that polypi are formed. Disease of the underlying bone, which by several authors has been looked upon as the primary cause, he considers secondiary, if it exists, to changes in the mucous membrane. 13riefly stated, the writer believes that on account of the structure of the mucous membrane from which polypi grow, a partial closing of the ducts of the glands accompanied by hypersecretion will tend to produce polypi. The sequence of events is as follows: (hronic inflammation of the mucous membrane, dilatation of the glands going on to cystic distention, eaused either by marked inflammatory infiltration of their ducts produced by septic discharges, or by excessive filling of the gland combined with a partial obstruetion to the exit of the gland contents. Then follows edemitous infiltration of the surrounding tissues, resulting from the passage of serum through the capillary walls, due to increased pressure in certain of the catpillaries, owing to obstruetion, and to increased permeability in the eapillary walls, the result of inflammation, and to the laxity of the surrounding tissues. This leads to the formation of folds or projections on the infiltrated mucous membrane, the increase of edema in certain of the folds combined later with a hyperplasia of the fibrous clements, the formation of flat edematous structures containing the essential constituents of the natsal mucous membrame, or of edematous structures containing the same constituents but a greater amount of fluid, and perhales of hyperplastic tissue, and each possessing a base which gradually becomes relatively constricted and stretched until it constitutes a pediele.

WTIOLOCIY OF DEVIATION OW 'THE SEP'TUM.

That the nasal septum of civilized man should deviate from the median plane in a large proportion of the race has been a matter of interest for years. With the introduction of constantly improving methods for correcting the deformity during the past fifteen years, many theories to account for its existence have been brought forward. Many of these were for obvious reasons unsatisfactory. Spurs and ridges were often looked upon as outgrowths of cartilage or bone, only accidentally commected with deviation of the scptum as a wholc. More recently deviations, when not obviously due to trauma, have been commonly considered to be the results of asymmetrical development, and spurs and ridges, dislocated or nisplaced portions of the septal cartilage or bone. While this asymmetrical growth is probably influenced by many factors, as is asymmetrical growth in other parts, no one factor, with the possible exception of trauma, satisfactorily accounts for the more common types of deviation, especially of the tendency of the lower border of the cartilage to dislocation along the upper border of the vomer. On this account the relation of deviation and spurs to the eruption of the permanent incisor teeth, recently studied by Mosher, ${ }^{2}$ is especially interesting. Linbryologically, the septum and the premaxillary bones are formed by the fusion of the mesial nasal processes. At birth the lower part of the septum is a shallow trough composed of three overlapping segments, - the vomer behind, the nasal spines in front, and between and connecting the two the premaxillary wings or subvomer bones,into which trough the quadrilateral cartilage and the perpendiculitr plate of the ethmoid dip from above. Bearing this in mind, it may easily be appreciated that the weakest points in the septum are the suture line between the perpendicu- 
lar plate and the vomer, and the point at which acessory simusitis. He had seen plates taken the vomer trough is overlapped by the trough for this purpose by killian, of Freibure, and in formed by the premaxillary wings. Any force March, 1905, published the results of ten cases that disturbs the nomal coaptation of these of radical operation in which skiagraphs had been constituent parts may produce deviation to one taken. Since that time several communieations sicle or the other. The sulvomer bones are have come from him on the suldect. His results, prominent offenders in this particular, produeing to pressure by hypertrophy, which hypertrophy is caused by irregular or clelayed cruption of the incisor teeth, the sockets of which are formed hy the premaxillary bones. When the two wings are symmetrically but only slightly enlatged they tip evenly outwiuld and produce basid spurs on either sicle of the septum anteriorly. When, however, the enlatgement is symmetrieal and at the sime time excessive, the tip of the septim is first pushed mpward and then to one side, with a resultant horizontal folding of the lower part of the eartilage upon itself. When the delay is milateral, the hypertrophy is on the delayed sicle only, the quadrilateral cartilage is tipped out of its bed along the vomer-ethmoid artieulation making a spur at this point and causing a deviation to the side opposite the hypertrophy.

(Ip to the eighth year, at which time the ossification of the septum is complete, tramma plays a minor part in producing deviations of the septum, as the force of blows is reduced by the elasticity of the cartilage. After this age tratuma is an important cause of deviation. Trauma by breaking one or both premaxillary wings and one or hoth leaves of the vomer ean produce. spurs and deviations iclentical with those produced by delayed eruption of the incisor teeth. Where trauma causes the deviation, the anterior border of the perpendicular plate of the ethmoid plays an important, rôle. 'This is the thickest part of the septum and the buffer against which hlows from the front expend themselves. If this border is oblicquely vertical, as it usually is, it is rightly placed to withstand trauma. If, on the other hand, it runs horizontally backward, it transmits the foree of the blow along the vomerethmoid articulation. The direction, therefore, of the anterior edge of the perpendicular plate of the ethmoid determines how far back on the septum the force of the blow will be folt. 'The typical deviation caused by tramma from the front is a double one. First, a vertical deviation and then a horizontal one into which the first merges. No rules can be given for deviations and spurs eaused by exeessive trauma from the front or from the sicle. The writer sums up his views as follows: A great, many spums and deviations are (atused by delayed eruption of the incisor teeth. After the teeth, tramma is the most commion (atuse of deviations of the septum. In many cases the teeth stant the deformity; tramma silpplements and increases it.

SKIAGRAPHY AS AN AIJ 'TO 'THE DIA(INOSIS ANI)

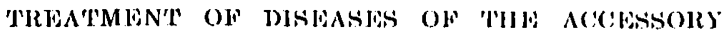
SINUSES OF 'IHE NOSL.

Coakley ${ }^{3}$ first, called the ationtion of the profession in this eomintry to the value of $x$-ray plates as an aid to diagnosis and treatmont of together with those of Mosher ${ }^{4}$ and ('hisholm " demonstrate conclusively the great value of such plates, especially in frontal sinus disease.

An antero-post and right and left side views should be taken in all cases. The antero-posterior plate shows the presence or absence of the sinus, the size of the sinus, the position of the complete septum separating the right and left sinuses, and the partial partitions, and the presence or alsence of an orbital prolongation. As in one third of all cases the frontal sinus does not come into the brow, but is simply an anterior ethmoid cell within the upper angle of the orbit, the plate olvviates the necessity of always making the initial opening at the root of the nasal bones, the only safe procedure previous to the use of the plates. (Houdiness over one sinus or in the ethmoid region denotes either pus or discased, polypoid or edematous mucous membrane. The side views corroborate the testimony of the antero-posterior plate in regard to the height of the sinus and the size of the orbital prolongation. In cases of diseased sinuses, in which the anteroposterior $x-r$ aty plate fats to show the outline clearly, the side views are of inestimable value, as in them the ontlines of the sinus come out clearly even when the sinus is filled with pus. They also show the depth of the frontal sinus and the extent of the hasal relationship between the floor of the sinus and the anterior ethmoid cells. This is of importance from the standpoint of prounosis as we may state before operation the probabilities of making a sizable opening into the nose insuring adequate drainage.

PNGUMOCOCCUS INFECTIONS OF THE ACClSsORY SINUSES.

In a preliminary communication founded upon fifty-two autopsies at Ancon, Isthmus of Panama, Darling "concludes that the portal of entry of the pneumococeus is, in most instances, an aceessory nasal sinus, the mucous membrane of which is probably fitted for the reception of the pnemococcus by an antecedent influenza or rhinitis. Of the autopsies 37 were pneumococeus infections, inclueling 222 lobar pnemonia, 1 acute pericarditis, 9 acute meningitis and 5 pneumococcus septicemia. Of these $92 \%$ showed in a very marked clegree pneumococens inflammation of one or more of the simuses. It is fibrino-purulent in character, fibrin and mononuclear cells being abundant. Pnemococei are always present and in numbers depending on the duration of the process. A point of great importance is the age of the sinus infection which has been appreciably greater than that of the lung or meningeal lesion.

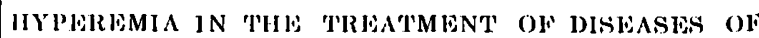
THE UPPBR AIR PASSAGirs.

The methods of Bier for the treatment of different diseases by inducing hyperemia has been 
studied by Polyak ${ }^{7}$ in eases involving the upper respiratory passiges. liollowing the technique of Keppler, passive eongestion of the hend is induced by an elastie bandare ahout the neck. The bandige should be so made that the degree of eonstriction can be easily altered; and especially if the effects of the hyperemia are desired in the larynx, it must loe placed as far down on the neck as posisible. It shomlal never be placed over the larynx, hut in the region of the thyroid gland, where it is generally tolerated by the patient, without discomfort, even at his meals. Although Bier recommended that the bandage be kept on for twenty out of the twenty-four hours, the author has reluced the time to eight or twelve hours a day, broken by two or three intermissions of an hour or two cach. In cases of disease of the larymx, especially tuberculosis, he begins with short periods, thirty minutes, noting the effects with the laryngoseope. The effects of this inruced congestion were often striking. Headache disilppeared in a few mimutes, and pain in swallowing in cases of acute tonsillitis and pharyngitis were often quickly relieved. 'This relief of pain was also obtained in cases of laryngeal tuberculosis, so that the condition of the patient was much improved. When the handage is removed, although the pain recurs, it is less rather than more acute as a result of the previous hyperemia.

A second method of inducing hyperemia eonsists in a special suction apparatus in which a (up) is applied over some local point in the pharynx, and the air exhausted by means of a rubber bull,. 'This suction is continued for a few minutes, and may be repeated if clesired. 'The author has obtained good results in cases of acute swelling of the tonsils, painful pharyngitis and crust, formation.

The author considers that it is well worth while to try induction of hyperemia in certain diseases of the upper air passages. The experiment is simple and has never given rise to serious complications. Nevertheless, it, should be carefully applied. At the beginning, at least, it should be under the olservation of a physician. 'This is especially true in cases of laryngeal tubereulosis, where edema of the latynx is possible. It may be of use in acute catarrhal and purulent processes with crust formation, torpid ulceration, tuberculosis and lupus. Although it is not easy to describe the exact, legree to which positive congestion should be earried, it may be said that it should never be distinctly uncomfortable for the patient, nor cause marked congestion nor headache. The proper degree is where a previous pain is at least relieved after a few mimutes.

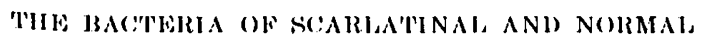
'THIROA'TH.

Ruediger ${ }^{8}$ has reported results of examinations of eultures from the tonsils of 154 eases, divided as follows: Normal 51; scarlatina 75; moasles 14; tonsillitis 5; pneumonia 5; pharyngritis 4. Streptococeus pyogenes was constantly found in great, numbers in all cases of searlet fever and tonsillitis. As a rule this organism arently predomi- nated over other colonies when the inflammation of the throat was pronounced and rapidly decreased in numbers with the subsidence of the throat symptoms. When the throat, symptoms were mild the proportion of the streplococeus colonies to other colonies was small. In normal throats the streptocoecus was found in $58 \%$ of the series examined, hut, was always present in small mumbers. The anthor eonsiders that it cammot be considered a normal inhabitant of all healthy throats. The streptococei from normal throats had a slightly greater virulenee for rahbits than those from scarlatinal throats, which agrees with the reported results of Hilbert "and 'Tumnicliff." Pnemonococei of low virulence were found in 135 of this series of 154 throats. The Commission for the Investigation of Acute Respiratory l)iseatses of the Health Department of the (ity of New York" found the pnemmococens in an equally large percentage of persons not afflicted with pneumonia. Klebs-l öeffler bacilli were found in 4 cases, which was to be expected, as innumeralble observers have reported present in normal throats in varying perecntages. Bacillus mucosus and bacillus influenza were cach found once. Staphylococeus aureus and citreus and microeoceus tetragenus were found occasionally, but were thought to be contaminations from the tomgue. Gram-negative diplocoeci which form small brownish colonies were found quite frequently. Nome of these were identified as micrococens cataprhalis. A large group of organisms which lies between the typical streptococeus pyogenes and pneumococeus was found in all normal throats and in nearly all discased throats. These organisms have little virulence for rabbits and, as they are found in great abundance in practically all throats, they would appear to be normal inhabitants.

\section{A DERINITA CONDITION OF IRIRITATION OF THW} LARYNGEAL NERVLS.

Among the neuroses of sensation of the larynx and its neighborhood Boenninghaus ${ }^{12}$ believes that certain symptoms oceur together frequently enough to constitute a definite pathological picture. 'lhe principal symptom is pain or discomfort, varying much in different cases, but accompanied by definite spots which are tender to pressure. This eondition arises generally as a sequel to inflammatory disturbinces of the pharynx, larynx and trachea. As these tender spots are found in the paths of the laryngeal nerves, it is probable that the symptoms are due t.o an irritation of these nerves. As this condition is a not infrequent one, and as it seems to be benefited by massage of the neck, the subject is one of practical importance. It is fully as common in men as in women, and very rare in ehildren. It may last for days or months or even years. 'The pain varies very much in different eases, but one very common characteristic is that the pain is aroused by the motions of swallowing when nothing is swallowed. The essential elenent in the diamnosis is the presence of certain definite spots sensitive to presisure, an upper spot between the 
greater cornu of the hyoid bone and the upper edge of the thyroid cartilage, that is, in the lateral part of the thyro-hyoid membrane; and a lower spot on the lateral border of the trachea. The patient will sometimes point out one of these spots as the seat of his trouble. In other cases they are diseovered by eareful manipulation, especial th attention being given to the relative sensitions of each side. 'T'reatment by massiage is generally effective, and the galvanic eurrent is also useful.

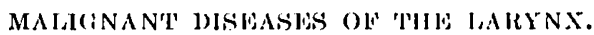

$\Lambda s$ is usual, much has been written on this important subject during the past year; and although nothing essentially new has been advancel since the last, review of the subject in the Journata, lieb. 5, 1904, the inereased numbers of reported results in operative cetses has made prognosis more definite and hopeful. All the writers aceentuate the necessity of early diannosis and the removal of the growth in its incipiency. Batginsky ${ }^{13}$ states that although extirpation of the larynx has become a less dangerous operation than formerly, and alter-treatment has been much improved, still the mortality is great, and early diangnosis holds out the only hope of permanent cure. Mackenzie ${ }^{14}$ advanees the view that injury to the growth due to excision for microscopical examination opens the pathway for metastatic invasion, and he makes a plea for diagnosis by exclusion without the aid of the microseope if possible. If, however, a piece must be removed for examination, let operation be immediate, if the growth prove malignant.

Jackson ${ }^{15}$ urges the frequent malignant nature of chronic hoarseness. The early curable statges of cancer of the larynx are chatacterized hy nothing but hoarseness, which may disappear and recur. (ough, odor, pain and glandular involvements are present only when the curable stage is passed. He reports is cases of thyrotomy and 8 cases of total laryngectomy. No immediate deaths occurred, which he modestly ascribes to good fortune; and the subsequent history of his cases show surprisingly good results. Of the 15 thyrotomies 5 were alive and well two years after operation. His conclusions are: Early diannosis is essential; if discovered early, the comparatively slight operation of thyrotony will cure. If discovered late, total or partial laryngectomy will probably prolong life for a variable period but recurrence is fairly certain.

In a recent paper Semon ${ }^{10}$ reviews the whole subject, his present views not differing materially from those of his earlier papers.

'WH W'TOLOGY AND PA'HOLOGX OF VOCAL NODULlis.

Miller ${ }^{17}$ has contributed an interesting and original article on this subject. Microscopically he has found nodules to consist of a superficial localized edema manifesting itself on the edge of of the cord, with little or no change in the epithelial layer either in the external hornified stratum or in its relation to the subepithelial connective tissuc. He found no evidence of an inflammatory process. Nodules may be traumatic in origin, such as those produced during violent coughing, in which case the nodule may appear at any point on the cord. On the other hand, the nodules caused by voeal weakness display a puzzling affinity for particular portions of the cords. They are generally found protruding from the anterior and middle third on one or both sides of the glottic opening. The traumatic nodule and what may be styled the vocal node are oftentimes simultaneously present, the traumatic nodule existing by itself in some irregular portion of the cord or superimposed upon or hended with the voeal node each to be distingruished by its well defined loeation, though produced by totally different causes. His theory as to the catusation of the typical nodes is at follows: $\Lambda$ great majority of the subjects present a follicular tonsillitis, aceompanying this there is more or less congestion of the mucous membrane of the larynx. 'This renders that portion over the vocal cords more liable to become edematous. It is further thought that there is a hyperactivity of certain fascieuli of the thyro-arytenoidens externus muscle, and that where these bundles cross the true cords there is produced localized edema or a singer's node. In support of this theory the author has succeeded in producing nodules experimentally in dogs. A tonsillitis was first produced by painting the fauces with cantharidal collodion and two days later rubbing on the surface a virulent culture of streptococei. 'Then through a slit-like opening in one side of the thyroid cartilage a small piece of the central portion of the thyro-arytenoideus muscle was removed, eonsisting of its whole thickness but not completely dividing the musele, in the hope that the nodes would be produced at the joints where these fasciculi pressed on the true cord. Examination with the laryngoscope after convalescence showed a node about where the post-fasciculus crossed the cord. This was confirmed by a postmortem examination. A very interesting fact was that, on splitting the larynx open from behind through the cricoid cartilage, the node disappeared. From this it is sugrested that nodes eannot be preserved after death.

GASTROSCOPY BY MEANS OF A MOIDFICATION OF 'IHE KILIAAN FSOPIAGOSCOPE.

Chevalier Jackson ${ }^{18}$ has devised a modifieation of the esophagoscope which he has used with suecess for direct inspection of the stomach for purposes both of diagnosis and treatment. The instrument is simply a lengthened esophagoscope with the lamp at the distal extremity of the tube as in the bronchoscope and esophagoscope previously devised by the author. For use in the arlult the tube is $9 \mathrm{~mm}$. in diameter and $80 \mathrm{~cm}$. in length. The light is carried on a removable light carrier which passes through a small auxiliary tube made in the wall of the main tube. When the carrier is in place the small lamp is at the extreme distal end of the gastroscope where it brilliantly illuminates the field without interfering with vision or instrumentation. Dry 
hatiferies are advised for lighting as the current from commercial lighting circuits may be " groundal " through the patient. 'The secretion aspirator, cotiton carrier and tube foreeps of increased length are used as in bronchoscopy or esophagoscopy. Ieep anesthesia is absolutely necessiary to prevent, retehing, and ether is the choice, as the anthor conviders ehloroform especially dangerous for gastroscopic: work. 'The tube is inserted in the usual way with the patient supine and the head well over the end of the table in Rosen's position. It is first passed to the erreater curvature and the anterior and posterior walls inspected. It is then partially withdrawn, inclined slightly laterally in the same plane and arain pushed downward in a new series of folds. After the whole possible range has been rovered in this way the tule is passed down until the extremity touches the wall of the ereater rurvature at the extreme left of the possible fieht. lt is then moved slowly alomer the groater eurvafure, hut, not, in too dose contace, mutil the extreme right is reached. This movement is repeated as many times as is necessary to cover the liedel as high as the cardia, the tube being withdrawn a centimeter or two with each repetition. Ablominal palpation may then be used to bring unexplored portions of the gitstric mucosa within the field. 'This sometimes is better accomplished by turning the patient from side to side; but during these latter manipulations the lube must be withdrawn from the esophagus, and reinserted when the stomach is in its new position. In a patient, with a normal stomach and esophagus the greater curvature for an extent of aloout, $14 \mathrm{~cm}$. and a considerable area of both the anterior and posterior walls may readily be explored without the aid of external manipulation. 'The fundus and pylorice coldis ean be brought; within range of the grastrosecope hy ehange of position of hy palpation. In the vertical of gastroptotic stomachs, the lester enrvalure, the pylorus and the pyloric third are casily seon with little or no exterial manipulation. 'The author reports diagmoses of gastritis, gasteoptosis, malignant discase of the cardia and the pylorus, cach in one instance; of peptic: uleer in three cases, one of which was cured by direct application.

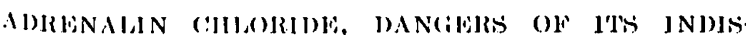

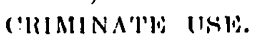

Aclrenalin has been a great boon to the intralasal operator, enabling him, as it does, to operate in a eomparatively dry ficld. That it is not, alway's an immoeent and harmless agent has been shown by the investigations of Josue, ${ }^{10}$ Jirb, ${ }^{20}$ Rzentkowski, Fisher, ${ }^{22}$ Pieree, ${ }^{23}$ and Stanton, during the past three years Josue first called attention to the fact that intravenous injections of adrenalin in the rabbit were followed by extensive changes in the aorta and larger vessels, and this observation has been corroborated by the results of the other observers. The change consists of localined destruction of the smooth musele fibers of the media accompanied by rapid ealcification and other characteristic alterations in the clastic tissue clements. Erb states that there is no act- ual similarity between this condition and the arterial sclerosis in the human subject. There is no sclerosis in the sense of a thickening due to proliferation of the intima, nor an atheromatous process, but there is apparently an analogry between the condition described and the calcification of the media as found in the large arteries of the extremities in man. Josue, ${ }^{25}$ in a more recent article, says that hypodermic injections may

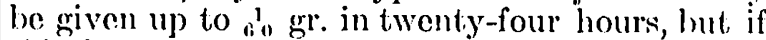
this dosage be exceeded there is danger of prolucing toxic effects. Applications to the unbroken nisial mucous membrane may be made without anticipation of untoward action. Adrenalin is often freely anplied in mid-operation in intranasal work, and the question becomes pertinent as to whether in so vascular a tissue as the mueous membrane of the nose, enough of the solution may not he absorbed through the eut surface to give rise to the immediate toxio symptoms and later vaseular changes. $\Lambda$ ease has recently heen reported of profound general disturlance? indueed by the injection of half a dram of $1-10(k)$ solution into the urethra for the purpose of checking blecting after the passinge of a sommd. The cut nasal mucous membrane would seem to offer as fair a chance of alosorption as the urethra.

I,ess serious than the above described conditions, but still of importance, are the local symptoms which may follow the longr-continued use of nasial sprays of adrenalin for the relief of hay fever. 13. II. Potts, ${ }^{27}$ has male a timely protest arainst the careless use of this drug, and reports several cases of persistent, turgesence of the nasial mucous membrane, due to long continued home use of adrenalin sprays by the patient.

MERHENeW.

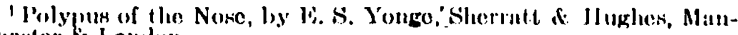
restor \& Jonton.

Read hefore the binstern Section of tho Amerienn baryngologi

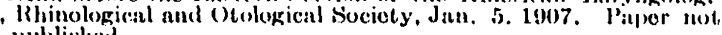
3 fublished.

Antu. of Otol., Rhinol. and Jaryngol, March, 1!005, p. 16.

s taryngoseope, Jel., 1002

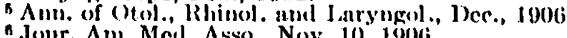

7 our. Am. Mol. Asso Nov. 10, 1906.

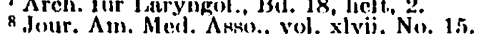

v \%eitechr. für llyg., 1809 , vol. xxxi, p. 3si.

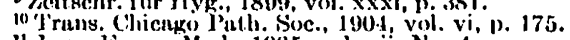

1. Jour. bixper. Med., 1005, vol. vii, No. 1 .

12 Arch. für laryngol., Bil. x viii, hefi, 2 .

13 Areut. für laryngol., Wad. xvii, hefi, 2 .

it Ann. Otol., lihinol. and Yarymgel., Mateh, 190.5.

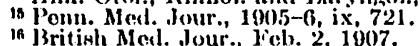

17 Ann. of Utol., Rhinol. and laryingel., Dee. 1906.

18 Ibidl.

10 Presse Modicale, 1003, xi, n. 708.

20) Verhandl. des (G)ngress für univers. Mled., 1901, xxi, p. 110.

21 lierl. klin. Wochenschr., 1004, xli, p. 8:30.

22 Mlunch. med. Wodiensehr., 1005, lii, p. 46.

23 ]auldauf: Am. Jour. Med. Sci. Nov., 1906

24 Mnel). Stunton: Jour. of lixp. Mnd., vol. viii, 1906, p. 74

25 J, a Quinizaine 'Therapeutique, $1006,50 . x x i v$, p. 562.

27 Jour. Am. Med. Asiso., Oct. 13, 1906, 1188.

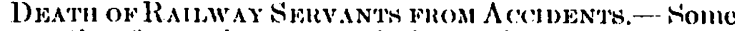
interesting figures have recently been given out showing the number of railway servants in England killed for each vear from 1896 to 1906 , both inclusive, in the movements of railway vehicles. The total number for eleven years was 5,241, and the yearly average mumber of deathis was somewhat over 470 . The worst year was 1900 with $5 \times 3$ deaths, and the best year was 1905 with 399 . - Brilish Medical Journal. 